\title{
THE MODERATING IMPACT OF ECONOMIC POLICY UNCERTAINTY ON THE RELATIONSHIP BETWEEN INVESTMENT IN WORKING CAPITAL AND PROFITABILITY
}

\author{
Abdul QUDDUS ${ }^{1 *}$, Drahomíra PAVELKOVÁ ${ }^{2}$, \\ Sarfraz HUSSAIN ${ }^{3}{ }^{3}$, Tien Phat PHAM ${ }^{4}$ \\ 1,2,4 Department of Finance and Accounting, Faculty of Management and Economics, \\ Tomas Bata University in Zlin, nám. T. G. Masaryka 5555, 76001 Zlín, Czech Republic \\ ${ }^{3}$ Commerce Department, Govt. Imamia College, Sahiwal, Pakistan
}

Received 23 February 2021; accepted 01 April 2021

\begin{abstract}
Purpose - Investment in working capital and firm profitability with economic policy uncertainty moderating effects has paid less attention in the existing literature. Therefore, this study examines the moderating impact of economic policy uncertainty on the relationship between Investment in working capital and firm profitability.

Research methodology - This study uses secondary data of 38 Pakistani chemical companies over the period of 20142019 using dynamic panel data methodology.

Findings - The dynamic panel analysis indicates that economic policy uncertainty moderates the relationship of investment in working capital and firm profitability significantly and positively. Overall, the study findings indicate that working capital management investment significantly affect accounting base performance of Pakistani chemical and pharmaceutical companies.

Research limitations - In this research, the researcher has collected data only from the non-financial sector. The financial industry can be used to carry the same study to get different results.

Practical implications - This study will help practitioners while making an investment decision in working capital management for firms because the results of this study contribute significantly to the firm's profitability.

Originality/Value - This research contributes favourable to a country's prospective investors at large and in the business's internal environment to manage the short-term liquidity issues during economic policy fluctuations.
\end{abstract}

Keywords: inventory turnover ratio, working capital management, cash conversion cycle, profitability, economic policy uncertainty.

JEL Classification: G3, G31, G11.

Conference topic: Contemporary Financial Management.

\section{Introduction}

The control of the acquisitions in existing properties and new capital funding shall be Working Capital Management (WCM). It includes establishing and enforcing a working capital management strategy in its day-to-day activities (Arunkumar \& Radharamanan, 2011). WCM is an essential element of corporate finance that is concerned with a company's short-term funding and financial choices (Sharma \& Kumar, 2011). Additionally, firms in respect of their size hold substantial amount since short-term payables are a big source of short-term financing for these companies; they have a lot of cash stashed away in the form of working capital (Badu Ebenezer \& Kwame Asiedu, 2013). In this aspect, funds invested in current assets can be seen as invisible sources which can help the company increase its effectiveness (ALShubiri, 2011). Therefore, WCM has a direct influence on a company's liquidity and profitability and its net value (Almazari, 2014). The components of WCM includes receivable turnover ratio (RTR), inventory turnover ratio (ITR), payable turnover ratio (PT), cash conversion cycle (CCC) to assess a firm's WCM efficiency relative to standard liquidity metrics (Costa, 2014). The current literature on WC management contains a range of

\footnotetext{
*E-mail: quddus@utb.cz
} 
viewpoints on its efficacy as a mechanism for improvement in firm performance. While one viewpoint contends that increasing WC investments, specifically over inventory, could boost sales, hedging offer input price and reduce costs of buying (Corsten \& Gruen, 2004). As a result, it is critical to understand the WC dynamics, specially how lowering or rising it to optimal levels can boost a company's valuation and operating efficiency (Aktas et al., 2015). Economic policy shifts have the potential to transform the economic climate in which businesses operate. For instance, monetary uncertainty about forthcoming policy of government has the probable to effect firm's decisions (Kang et al., 2014). It causes a disruption in the movement of goods and services in a supply chain, as well as increased compression on businesses WC, that can restrict their entrance to credit (Bordo et al., 2016). Economic policy uncertainty (EPU) is a hazard related to government policy, instability caused by uncertain potential policies and regulatory structures. The study of Gilchrist et al. (2014) and Pastor and Veronesi (2012) show that political uncertainty boosted financing cost, reduced investment, and accelerated economic contraction. In this study, we examine that how EPU affects WC components (RD, ITR, PD, and CCC) as well as profitability in Pakistani manufacturing firms. Maintaining levels of inventory and payables, as well as the risks involved with them, is a constant challenge for businesses ( $\mathrm{Li}$ et al., 2013). Baker et al. (2016) created the EPU Index, which this study uses to calculate economic policy uncertainty. We confirm that Monetary Policy Uncertainty and EPU, a subgroup of EPU characterized by increased volatility due to uncertainty in monetary policy, the degree of WC components is affected by EPU. The impact of increasing levels on firms' liquidity positions has been lauded. Despite the statistical importance of the findings, the outcomes indicate that EPU has a slight impact on WC and profitability.

The following are the key contributions of this study. To the best of authors knowledge, this is the first novel study that examines the effect of EPU on the components of WC and profitability. The study shows that the EPU is negatively moderates the WC variables and profitability relationship. The cost of high uncertainty to the economy leads to spend more in firms working capital. EPU also has an effect on inventory at whole intensities of output, by the higher influence on finished products. Moreover, the study uses panel data, dynamic regression methodology to draw better results because variables be contingent intensively on the lagged values. This study posits managers with methods and insights on controlling working capital and in what way to run inventory resourcefully while keeping a short-term liquidity during the economic uncertainty fluctuations. The organization of the paper is as follow: first, an introduction and literature review in the current field; second describes methodology, third, the conclusions, and robustness tests are discussed. The limitations and conclusion are presented in final section.

\section{Theoretical development}

\subsection{Components of working capital management and EPU}

Prasad et al. (2019) have analysed the influence of WCM and established that WCM is an essential part for organization to achieve better profitability. Afrifa (2015) explores the effects on small-mediums' enterprises viability listed on the alternative investment sector of working capital activities. There is a link between expenditure and profitability for working capital was discovered (Baños-Caballero et al., 2014). Panda and Nanda (2018) investigated the relationship between productive and working capital management of Indian 1211 manufacturing firms for 2000-2016 (2018); the findings showed the U-shaped relationship in the chemical, construction, and consumer product sectors. The association among the productivity of working capital and market performance in the manufacturing industries is investigated by (Ukaegbu, 2014). The findings of the analysis indicate that profitability is highly adversely linked with WCM. Enqvist et al. (2014) indicates the significant effect on all business performance listed between 1990 and 2008 of working capital management. The study indicated that components of WCM have significant impact on the profitability, meaning that these components are more definitive during the economic crises. Oseifuah and Gyekye (2017) explored the relationship between working capital and profitability in the South African economy and show that the components of WCM have positive influence on the profitability of firm. The authors further suggest that working capital plays an essential role in creation wealth. Both components of WC, Accounts receivable (AR) and accounts payable (AP) calculated by trade credits, have been studied in several studies (Lo et al., 2009; Seifert et al., 2016), these financial mechanisms, in particular, has enabled the supply chain to manage asymmetric information among those in need of capital and capital markets (Pfohl \& Gomm, 2009). Lee et al. (2018) studied that in what way trade credit increases supply chain productivity by enabling retailers to manage certain market risks with suppliers. This WC literature acknowledged that even a supply chain's capital inflows can be improved by assisting suppliers and buyers in enhancing their WCs and lowering costs (Wuttke et al., 2013). So many studies have focused on maximizing a business's financial performance by lowering the WC and decrease the amount, cost, or length of financing options, which can be done by determining the best AP, AR, and inventory policies (Theodore Farris \& Hutchison, 2002; Gelsomino et al., 2016). The study of Gaur and Kesavan (2015) indicates that inventory turnover rises in line with sales growth. Further, Sahari et al. (2012) shows that inventory turnover is positively associated with the firm's profitability. When CCC rise, the profitability of the firm has decline, so there is negative relation observed by (Ren et al., 2019). Altaf and Shah (2017) indicate that the inverted U-shape association among profitability and the CCC, 
component of WC. In general, previous research has revealed a positive association among components of WCM and firm performance. Thus, the hypothesis is as follows:

\section{H1: There is a positive relationship between components of WCM and firm profitability.}

Many studies suggested that businesses reduce their investment and employment in uncertain times during EPU is high because the operating environment is high-risk (Deloof, 2003). Furthermore, the EPU raises the cost of funding businesses, making banks fewer likely to disburse to them (Bordo et al., 2016). Enterprises with various characteristics, on the other hand, are ideally placed to mitigate the negative effects of volatility because they depend on financing internally (Wang et al., 2014). Therefore, Contextual factors to firm-specific attributes, can influence a firm's activities. Dbouk et al. (2018) indicates that firms in competitive business environments intend to raise their WC investments in addition to growing uncertainty, as delaying investments is inclined to make them least competitive in the longer term. Integrating EPU as an external predictor factor into volatility models has greatly enhanced stock market volatility forecasting. Baker et al. (2016) suggests that EPU predict market cycle fluctuations which cause higher or lower impact on overall health of business. Chen et al. (2005) studied an inventory in non-financial firms and show that indicators of EPU like interest rates, inflation, and GDP have an impact on levels of inventory. Likewise, Kesavan et al. (2016) investigated how retailers react to economic policy risk by having high or low inventory turnover, as well as the effect on their financial health. They showed that once the inventory turnover is higher, vendors respond by adjusting their buying amounts, which is normally done rapidly. Finally, the Table 1 shows the summary of relevant studies on WCM and firm performance. Overall, EPU is anticipated to have a moderating impact on the investment and firm performance. Therefore, the study's second hypothesis would be:

\section{H2: EPU has a negative moderating impact on the relationship between CCC and firm profitability.}

Table 1. Summary of relevant studies on WCM and firm performance (source: created by authors)

\begin{tabular}{|c|c|c|c|c|}
\hline No. & Authors' & Purpose & Major Findings & Context \\
\hline 1 & Ahangar (2021) & $\begin{array}{l}\text { This article intends to explore the } \\
\text { link between WCM and profitable } \\
\text { results for a sample of } 2,122 \text { Indian } \\
\text { SMEs. }\end{array}$ & $\begin{array}{l}\text { The two-step measurements of GMM } \\
\text { establish an inverted U-shaped association } \\
\text { between WCM and a company's } \\
\text { profitability. }\end{array}$ & $\begin{array}{l}\text { Manufacturing } \\
\text { Firms }\end{array}$ \\
\hline 2 & $\begin{array}{l}\text { Anton and Nucu } \\
(2021)\end{array}$ & $\begin{array}{l}\text { The purpose of this analysis is to } \\
\text { explore the link between working } \\
\text { capital and business profitability. }\end{array}$ & $\begin{array}{l}\text { The analysis findings indicate that } \\
\text { labour capital has an inverted U-shaped } \\
\text { relationship between working capital } \\
\text { and corporate profitability that positively } \\
\text { impacts profitability. }\end{array}$ & $\begin{array}{l}\text { Polish Listed } \\
\text { Firms }\end{array}$ \\
\hline 3 & $\begin{array}{l}\text { Baig et al. } \\
\text { (2021) }\end{array}$ & $\begin{array}{l}\text { This analysis's primary purpose is to } \\
\text { assess the effect of profitability and } \\
\text { working capital in the long term. }\end{array}$ & $\begin{array}{l}\text { The results indicated that various industries } \\
\text { had different working capital investments in } \\
\text { the long-term mix. }\end{array}$ & $\begin{array}{l}\text { Non-financial } \\
\text { Firms }\end{array}$ \\
\hline 4 & $\begin{array}{l}\text { Siraj et al. } \\
(2021)\end{array}$ & $\begin{array}{l}\text { This research attempts to analyze } \\
\text { labor resource optimization to } \\
\text { improve profitability. }\end{array}$ & $\begin{array}{l}\text { The handling of working capital as a whole } \\
\text { is not satisfactory, as it is below the Limited } \\
\text { Partnership Company level. }\end{array}$ & $\begin{array}{l}\text { Limited } \\
\text { Company } \\
\text { Telkomsel }\end{array}$ \\
\hline 5 & $\begin{array}{l}\text { Amponsah- } \\
\text { Kwatiah and } \\
\text { Asiamah (2020) }\end{array}$ & $\begin{array}{l}\text { This research analyzes the effect } \\
\text { of the management of working } \\
\text { capital on the profitability of listed } \\
\text { companies in Ghana. }\end{array}$ & $\begin{array}{l}\text { The survey indicates that working capital } \\
\text { management components have a favorable } \\
\text { effect on assets' return and return on } \\
\text { equities. }\end{array}$ & $\begin{array}{l}\text { Manufacturing } \\
\text { firms }\end{array}$ \\
\hline 6 & Sattar (2019) & $\begin{array}{l}\text { This research aims to evaluate the } \\
\text { medial influence of WCM on capital } \\
\text { structure determinants. }\end{array}$ & $\begin{array}{l}\text { The findings indicate that working capital } \\
\text { plays an essential function in the structure } \\
\text { of capital and its determinants. }\end{array}$ & $\begin{array}{l}\text { Non-financial } \\
\text { companies }\end{array}$ \\
\hline 7 & $\begin{array}{l}\text { Kabuye et al. } \\
\text { (2019) }\end{array}$ & $\begin{array}{l}\text { This paper is intended to analyze } \\
\text { the relation to financial results by } \\
\text { internal management mechanisms and } \\
\text { working capital. }\end{array}$ & $\begin{array}{l}\text { The findings show that internal management } \\
\text { mechanisms and operating resources } \\
\text { are significantly linked to financial } \\
\text { performance; the only significant economic } \\
\text { performance indicator is working capital. }\end{array}$ & $\begin{array}{l}110 \\
\text { Supermarkets }\end{array}$ \\
\hline 8 & $\begin{array}{l}\text { Abdullah and } \\
\text { Siddiqui (2019) }\end{array}$ & $\begin{array}{l}\text { The analysis seeks to investigate the } \\
\text { complex partnership between work } \\
\text { capital funding and sustainability of } \\
\text { the business. }\end{array}$ & $\begin{array}{l}\text { In summary, the study shows that a } \\
\text { company's profitability does not rely on } \\
\text { expenditures in the fertilizer, cement and } \\
\text { consumer sector working capital. }\end{array}$ & $\begin{array}{l}\text { Chemical, } \\
\text { Cement \& } \\
\text { FMCG sector }\end{array}$ \\
\hline 9 & $\begin{array}{l}\text { Mazlan and } \\
\text { Leng (2018) }\end{array}$ & $\begin{array}{l}\text { This research seeks to suggest a } \\
\text { contemporary paradigm for handling } \\
\text { working resources. }\end{array}$ & $\begin{array}{l}\text { There are significant variations in the } \\
\text { amount of working capital of all the firms } \\
\text { in the study. }\end{array}$ & $\begin{array}{l}\text { Manufacturing } \\
\text { firms }\end{array}$ \\
\hline 10 & $\begin{array}{l}\text { Altaf and Shah } \\
\text { (2017) }\end{array}$ & $\begin{array}{l}\text { This paper looks at the connection } \\
\text { between working capital and } \\
\text { corporate efficiency. }\end{array}$ & $\begin{array}{l}\text { The findings indicate that the relationship } \\
\text { between job resources and organizational } \\
\text { efficiency is inverted U-shaped. }\end{array}$ & $\begin{array}{l}\text { non-financial } \\
\text { companies }\end{array}$ \\
\hline
\end{tabular}




\subsection{Conceptual model}

Based on the discussion above, the conceptual model is proposed in Figure 1, which show components of WCM as an independent variable, size of firm is a control variable, the EPU as moderating variable and Return on assets (ROA) and Return on equity (ROE) as a dependent variable.

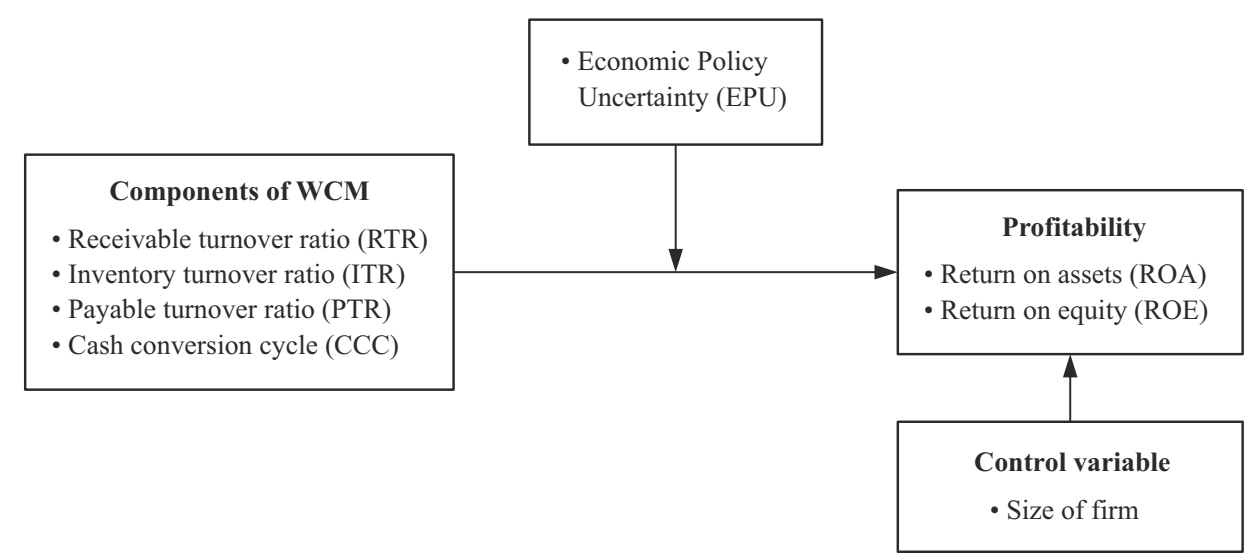

Figure 1. Theoretical framework (source: created by authors)

\section{Research methodology}

A total of 38 registered Pakistani chemical companies included in the study sample. The first chemical sector was intended to prevent skewed results or specific circumstances, such as the effect of EPU on the relationship of investment in WCM and firm profitability.; all of the corporations studied are trading on the Pakistan Stock Exchange (PSX). The data were collected from the Department of Statistics covers six years from 2014 to 2019.

In this research, the ROA and ROE has used as the firm profitability variable; as a consequence, it is referred to as the dependent variable. The study sought to link the organization's profitability, so this variable was included. The primary aim of this research is to find profoundly impact effect of EPU on the relationship of investment in WCM and firm profitability in the context of chemical sector. Predictor or regressor variables are the components of WCM, RTR, ITR, PTR, CCC, while firm size, is a control variable and EPU is a moderator variable for the study. The Table 2 shows the descriptions of study variables.

Table 2. Descriptions of study variables (source: created by authors)

\begin{tabular}{|l|l|l|}
\hline \multicolumn{2}{|c|}{ Variable of the study } & \multicolumn{1}{c|}{ Measures } \\
\hline Firm Profitability & ROA & "Net income to total assets" \\
\cline { 2 - 3 } & ROE & "Net income to shareholder's equity" \\
\hline Receivable turnover ratio & RTR & "Dividing net sales by net receivables on average" \\
\hline Inventory turnover ratio & ITR & "Cost of Goods Sold to Average Inventory" \\
\hline Payable turnover ratio & PTR & "Total Supplier purchase to Average Account payable" \\
\hline Cash conversion ratio & CCC & $\begin{array}{l}\text { "Inventory outstanding (days)+ Account Receivable (Days) - } \\
\text { Account payable (days)" }\end{array}$ \\
\hline Economic Policy Uncertainty & EPU & $\begin{array}{l}\text { "EPU is measured through EPU Index." } \\
\text { www.policyuncertainty.com }\end{array}$ \\
\hline Firm size & "Natural logarithm of total assets" \\
\hline
\end{tabular}

\subsection{Research models}

The paper investigates how variables influence profitability of a firm using dynamic panel data analysis of cross-sectional time-series from 2014 to 2019. ROA and ROE will be used as a dependent variable alongside several other variables, so it can be described as follows:

\subsection{Dynamic panel models}

A regression equation are as follows: 


$$
\begin{aligned}
& \operatorname{ROA}_{i t}=\beta_{i t}+\beta_{1}\left(\operatorname{RTR}_{i t}\right)+\beta_{2}\left(\operatorname{ITR}_{i t}\right)+\beta_{3}\left(\mathrm{PTR}_{i t}\right)+\beta_{4}\left(\mathrm{CCC}_{i t}\right)+\beta_{5}\left(\mathrm{EPU}_{i t}\right)+\beta_{6}\left(\mathrm{SIZE}_{i t}\right)+\varepsilon_{i t} \\
& \mathrm{ROA}_{i t}=\beta_{i t}+\beta_{1}\left(\mathrm{RTR}_{i t}\right)+\beta_{2}\left(\mathrm{ITR}_{i t}\right)+\beta_{3}\left(\mathrm{PTR}_{i t}\right)+\beta_{4}\left(\mathrm{CCC}_{i t}\right)+\beta_{5}\left(E P U_{i t}\right)+\beta_{6}\left(\mathrm{EPU}^{*} \mathrm{CCC}_{i t}\right)+\beta_{7}\left(\mathrm{SIZE}_{i t}\right)+\mu_{i t}
\end{aligned}
$$

$\mathrm{ROE}_{i t}=\beta_{i t}+\beta_{1}\left(\mathrm{RTR}_{i t}\right)+\beta_{2}\left(\mathrm{ITR}_{i t}\right)+\beta_{3}\left(\mathrm{PTR}_{i t}\right)+\beta_{4}\left(\mathrm{CCC}_{i t}\right)+\beta_{5}\left(\mathrm{EPU}_{i t}\right)+\beta_{6}\left(\mathrm{SIZE}_{i t}\right)+\varepsilon_{i t} ;$

$\mathrm{ROE}_{i t}=\beta_{i t}+\beta_{1}\left(\mathrm{RTR}_{i t}\right)+\beta_{2}\left(\mathrm{ITR}_{i t}\right)+\beta_{3}\left(\mathrm{PTR}_{i t}\right)+\beta_{4}\left(\mathrm{CCC}_{i t}\right)+\beta_{5}\left(\mathrm{EPU}_{i t}\right)+\beta_{6}\left(\mathrm{EPU}^{*} \mathrm{CCC}_{i t}\right)+\beta_{7}\left(\mathrm{SIZE}_{i t}\right)+\mu_{i t}$,

where $i(i=1 \ldots 38)$ is the intercept for each entity, $t(t=2014-2019), \beta$ are the coefficients for each regressor variable, which describe the years studied, including $\varepsilon_{i t}$ as the disturbance term and $\left(\mathrm{EPU} \mathrm{U}_{i t}{ }^{* \mathrm{CCC}}\right)$ is the interaction term between cash conversion cycle and economic policy uncertainty. The $\mu$ it goes when a one-way disturbance ingredient models $\mu_{i t}=\lambda_{i}+\varepsilon_{i t}$ the error term $\mu$ it is de-integrated into $\lambda_{i}$ and $\varepsilon_{i t}$. The $\lambda_{i}$ individual-specific effect comprises the individual heterogeneity and $\varepsilon_{i t}$ is the error term. Therefore, to handle possible endogeneity, this study employed lagged term of the dependent variable using a system estimator of the generalized methods of moments (GMM) (Blundell et al., 2001). The efficiency of the instruments' calculations and validation relies on the absence of a first and second-order serial connection (AR1), (AR2) in the residuals (Arellano \& Bond, 1991). In the entire estimation study report (AR2), there is no second-order serial correlation for the error terms in the regressions. Moreover, the instrument validity is evaluated through the Hansen test that estimates the designated instruments' joint validity.

\section{Results}

\subsection{Descriptive statistics}

The descriptive statistics has provided in Table 3 for each variable. A first approach to the association between corporate investment in WCM and firm profitability has shown in the above figure, which also estimated the analysis of the EPU over the considered period. Our sample's firms have an average ratio to ROA and ROE is 5.26 and 13.59 respectively, whereas it rises to the value of 4.45 when considering EPU. Regarding RTR and ITR, the data show that, on average, it presents punctuation of 4.32 and 11.83 when considering the firm profitability value. Further, the study offers a relatively low value of the standard deviation of EPU, 0.22, and higher for PTR, CCC, and size, respectively, to ROA and ROE. Regarding the maximum and minimum values, all independent variables present smooth behavior for a particular study.

Table 3. Descriptive statistics (source: created by authors)

\begin{tabular}{|c|c|c|c|c|c|c|c|c|}
\hline & Mean & Median & Maximum & Minimum & Std. Dev. & Skewness & Kurtosis & Observations \\
\hline ROA & 5.26 & 5.76 & 36.94 & -156.68 & 16.03 & -6.01 & 62.13 & 171 \\
\hline ROE & 13.59 & 13.13 & 303.22 & -206.90 & 39.66 & 1.67 & 27.18 & 171 \\
\hline RTR & 4.32 & 4.48 & 7.77 & -4.52 & 1.60 & -0.93 & 7.43 & 171 \\
\hline ITR & 11.83 & 6.40 & 146.07 & 0.00 & 19.96 & 4.27 & 22.72 & 171 \\
\hline PTR & 33.14 & 12.63 & 886.86 & 0.00 & 97.24 & 6.30 & 46.71 & 171 \\
\hline CCC & 4.28 & 4.42 & 7.76 & 0.06 & 1.56 & -0.16 & 2.74 & 171 \\
\hline SIZE & 15.16 & 15.41 & 19.00 & 11.62 & 1.77 & -0.21 & 2.58 & 171 \\
\hline EPU & 4.45 & 4.61 & 4.65 & 4.15 & 0.22 & -0.46 & 1.26 & 171 \\
\hline
\end{tabular}

\subsection{Correlations}

Table 4 presents Pearson correlations among the variables. The RTR and PTR, CCC and size are positively correlated with firm profitability measures (ROA and ROE). As can be seen, the correlation coefficients among the ITR and EPU are negatively correlated, with the idea that a higher level of EPU decreases the level of investment in WCM and firm profitability. CCC is positively correlated to ROA and ROE, which means higher CCC contributes significantly to a firm; conversely, ITR presents a negative correlation to profitability measures. Finally, multicollinearity is not a problem between the variables.

Table 5 reports the analysis of the moderating impact of economic policy uncertainty on the relationship between investment in working capital and profitability. The components of investment in WCM include RTR, ITR, PTR, 
A. Quddus, D. Pavelková, S. Hussain, T. P. Pham. 2021. The moderating impact of economic policy uncertainty on the relationship between investment in working capital and profitability

Table 4. Correlation matrix (source: created by authors)

\begin{tabular}{|c|c|c|c|c|c|c|c|c|}
\hline Probability & ROA & ROE & LRTR & ITR & PTR & CCC & SIZE & EPU \\
\hline ROA & 1 & & & & & & & \\
\hline \multirow{2}{*}{ ROE } & -0.1709 & 1 & & & & & & \\
& 0.0254 & ----- & & & & & & \\
\hline \multirow{2}{*}{ RTR } & 0.1659 & -0.0835 & 1 & & & & \\
& 0.0302 & 0.2777 & ---- & & & & \\
\hline \multirow{2}{*}{ ITR } & -0.1098 & -0.0735 & -0.0557 & 1 & & & & \\
& 0.1529 & 0.3397 & 0.4691 & ---- & & & \\
\hline \multirow{2}{*}{ PTR } & 0.0426 & -0.0426 & 0.1518 & -0.0346 & 1 & & & \\
& 0.5803 & 0.5798 & 0.0475 & 0.6532 & ---- & & & \\
\hline \multirow{2}{*}{ CCC } & 0.0754 & -0.1046 & 0.9099 & 0.0858 & 0.1775 & 1 & & \\
& 0.3267 & 0.1733 & 0.0000 & 0.2647 & 0.0202 & ---- & & \\
\hline \multirow{2}{*}{ SIZE } & 0.0306 & 0.1279 & 0.2185 & -0.0222 & -0.0565 & 0.1808 & & 1 \\
\hline \multirow{2}{*}{ EPU } & 0.6909 & 0.0956 & 0.0041 & 0.7730 & 0.4628 & 0.0180 & - & \\
& -0.0235 & 0.1003 & -0.0098 & 0.0328 & 0.0128 & -0.0053 & 0.0381 & \\
\hline
\end{tabular}

Table 5. Linear and nonlinear regression (source: created by authors)

\begin{tabular}{|c|c|c|c|c|c|c|c|c|}
\hline & \multicolumn{2}{|c|}{ (1) } & \multicolumn{2}{|c|}{ (2) } & \multicolumn{2}{|c|}{ (3) } & \multicolumn{2}{|c|}{ (4) } \\
\hline Variables & \multicolumn{2}{|c|}{ SysGMM ROA } & \multicolumn{2}{|c|}{$\begin{array}{l}\text { SysGMM ROA } \\
\text { with moderator }\end{array}$} & \multicolumn{2}{|c|}{ SysGMM ROE } & \multicolumn{2}{|c|}{$\begin{array}{l}\text { SysGMM Roe } \\
\text { with moderator }\end{array}$} \\
\hline $\mathrm{ROA}=\mathrm{L}$ & \multicolumn{2}{|c|}{$\begin{array}{c}-0.278^{* * * *} \\
(0.0412)\end{array}$} & \multicolumn{2}{|c|}{$\begin{array}{c}-0.269 * * * \\
(0.0424)\end{array}$} & & & & \\
\hline $\mathrm{ROE}=\mathrm{L}$ & & & & & $\begin{array}{l}0.1 \\
(0 .\end{array}$ & & $\begin{array}{r}0.0 \\
(0\end{array}$ & \\
\hline RTR & \multicolumn{2}{|c|}{$\begin{array}{c}5.452 * * * \\
(1.601)\end{array}$} & \multicolumn{2}{|c|}{$\begin{array}{c}5.785^{* * *} \\
(1.526)\end{array}$} & \multicolumn{2}{|c|}{$\begin{array}{c}-13.61 * * * \\
(2.492)\end{array}$} & \multicolumn{2}{|c|}{$\begin{array}{c}-9.931 * * * \\
(2.786)\end{array}$} \\
\hline ITR & \multicolumn{2}{|c|}{$\begin{array}{c}0.0108 \\
(0.0297)\end{array}$} & \multicolumn{2}{|c|}{$\begin{array}{c}-0.00228 \\
(0.0288)\end{array}$} & \multicolumn{2}{|c|}{$\begin{array}{l}-0.0118 \\
(0.0333)\end{array}$} & \multicolumn{2}{|c|}{$\begin{array}{c}0.0209 \\
(0.0355)\end{array}$} \\
\hline PTR & \multicolumn{2}{|c|}{$\begin{array}{c}0.0238^{* * *} \\
(0.00333)\end{array}$} & \multicolumn{2}{|c|}{$\begin{array}{l}0.0224 * * * \\
(0.00330)\end{array}$} & \multicolumn{2}{|c|}{$\begin{array}{c}0.0454 * * * \\
(0.0152)\end{array}$} & \multicolumn{2}{|c|}{$\begin{array}{c}0.0494 * * * \\
(0.0178)\end{array}$} \\
\hline $\mathrm{CCC}$ & \multicolumn{2}{|c|}{$\begin{array}{l}-5.040^{* * *} \\
(1.603)\end{array}$} & \multicolumn{2}{|c|}{$\begin{array}{c}-14.07 * * * \\
(2.533)\end{array}$} & \multicolumn{2}{|c|}{$\begin{array}{c}7.040 * * * \\
(2.509)\end{array}$} & \multicolumn{2}{|c|}{$\begin{array}{c}2.063 \\
(9.797)\end{array}$} \\
\hline SIZE & \multicolumn{2}{|c|}{$\begin{array}{l}-4.876^{* * *} \\
(1.101)\end{array}$} & \multicolumn{2}{|c|}{$\begin{array}{c}-4.998 * * * \\
(1.112)\end{array}$} & \multicolumn{2}{|c|}{$\begin{array}{c}17.61 * * * \\
(1.172)\end{array}$} & \multicolumn{2}{|c|}{$\begin{array}{c}17.37 * * * \\
(1.391)\end{array}$} \\
\hline EPU & \multicolumn{2}{|c|}{$\begin{array}{c}2.220 \\
(1.580)\end{array}$} & \multicolumn{2}{|c|}{$\begin{array}{c}-6.572 * * * \\
(2.514)\end{array}$} & \multicolumn{2}{|c|}{$\begin{array}{l}-1.002 \\
(3.005)\end{array}$} & \multicolumn{2}{|c|}{$\begin{array}{l}-3.320 \\
(9.246)\end{array}$} \\
\hline $\mathrm{EPU}{ }^{*} \mathrm{CCC}$ & & & \multicolumn{2}{|c|}{$\begin{array}{c}2.013 * * * \\
(0.548)\end{array}$} & & & \multicolumn{2}{|c|}{$\begin{array}{l}0.500 \\
(1.997)\end{array}$} \\
\hline Constant & $\begin{array}{r}67 . \\
(1\end{array}$ & & & & $\begin{array}{r}-22 \\
(2\end{array}$ & & $\begin{array}{r}-20 \\
(4\end{array}$ & \\
\hline Observations & & & & & & & & \\
\hline Number of Firms & & & & & & & & \\
\hline Diagnostic Test & Stat & Pval & Stat & Pval & Stat & Pval & Stat & Pval \\
\hline $\begin{array}{l}\text { Sargan test } \\
\text { chi2 } \mathrm{P}(\text { value })\end{array}$ & 19.246 & 0.1157 & 19.411 & 0.1109 & 14.3615 & 0.3489 & 15.2951 & 0.2893 \\
\hline $\begin{array}{l}\text { Arellano-Bond test } \\
\text { for AR(1) P(Value) }\end{array}$ & -0.6175 & 0.5369 & -0.6648 & 0.5062 & -1.4474 & 0.1478 & -1.4161 & 0.1567 \\
\hline $\begin{array}{l}\text { Arellano-Bond test } \\
\text { for AR(2) P (value) }\end{array}$ & -1.4135 & 0.1575 & -1.3391 & 0.1805 & .34802 & 0.7278 & .41116 & 0.6810 \\
\hline
\end{tabular}

Notes: Standard errors in parentheses $* * * \mathrm{p}<0.01, * * \mathrm{p}<0.05, * \mathrm{p}<0.1$, The dependent variable are Return on equity (ROE) and Return on assets (ROA) representing firm profitability, while RTR, ITR, PTR, CCC are independent variables size is control variable and EPU*CCC is the moderator variables in the model. 
CCC employed dynamic pattern. Table 5 presents the study's linear and non-linear regression models finding using dynamic panel analysis where ROA and ROE are used as the dependent variable. At the same time, economic policy uncertainty is used as interaction with CCC variable. The analysis also makes a situation in contradiction of estimating panel equations A.R. parameters (Hambuckers \& Ulm, 2020) instead of one autocorrelation (A.R.) parameter for all panels. The results from the Two-Step system GMM regression are included in all columns. The column 1 and 3 shows the linear regression results, while 2 and 4 indicate non-linear results. Th both lagged dependent variables value in the dynamic SysGMM is significant in the model which shows that our outcomes are consistent. The linear regressions show that RTR, PTR have a positive relationship with ROA but RTR has significant and negative with ROE. The CCC and size also hold negative and significant with ROA, while ITR has negative relationship with ROE. Furthermore, the EPU indicate more consistent results with ROE, besides that it shows insignificant relation with ROA. It means that when EPU rises than cash conversion cycle of a firm decreased.

The outcomes of the non-linear regression analysis indicate that RTR and PTR have significant positive relationship with ROA, while CCC and size hold negative and significant association with Profitability. Furthermore, the interaction term between EPU*CCC show positive and significant relationship with ROA. It means economic policy uncertainty positively moderates the cash conversion cycle of the firms in the sample. On the other hand, RTR and EPU hold negative relationship, while PTR and size have positive and significant association with ROE. Therefore, overall the moderating variable EPU moderates the relationship of the component of WCM and profitability of the firm, which means when EPU increased profitability also increased and vice versa.

\section{Discussion}

This paper examines whether EPU moderates the relationship of investment in WCM and firm profitability of 38 chemical firms on the Pakistani Stock Exchange from 2014 to 2019. Two hypotheses were developed based on the literature review to investigate the direct and indirect effects on the relationship between investment in WCM components and profitability. The SysGMM technique have used to approximate two hypotheses on four-panel data empirical equations. When the EPU rises in the economy, firms' corporate investments in WCM also increased. The loss of those investments is attributed to a firm's profitability. As EPU grows, investors and corporate executives become more concerned about risk, and firm performance suffers as a result. We find that EPU has a significant positive moderating impact on firm profitability using a proxy of ROA as a firm profitability in the Pakistani Chemical firms. Since it reflects a firm's accounting base performance over assets, the EPU coefficient is higher on ROA. As a result, inventory prices respond more rapidly when EPU increases. Corporate policymakers, venture capitalists, investment firms, and business managers all use the EPU index to evaluate overall uncertainty. Our findings suggest that all participants in a company would take all reasonable precautions to avoid losses caused by uncertainty. Regulatory authorities, for example, are one of the most key stakeholders in companies, and they should be conscious that uncertainty about regulator decisions will harm company profitability if the decision is made improperly.

\section{Conclusions}

We analyze the moderating impact of EPU on the relationship between investment in WCM and firm profitability of 38 chemical firms on the Pakistani Stock Exchange from 2014 to 2019. Our main finding is that the effect of EPU on components of WCM investment and firm profitability is significant and positive to ROA. In terms of evaluating the effect of economic policy uncertainty as a moderating variable on the components of WCM and firm output of chemical and pharmaceutical companies. Our study is the first in the authors' best knowledge, confirming that Uncertainty increases the importance of the alternative to wait before further information on ventures' feasibility is disclosed. We employed SysGMM analysis to avoid endogeneity issues.

Moreover, the overall moderate regression findings suggest that the relationship between WCM investment components and ROA is positively and significantly moderated by the EPU. The study findings indicate that WCM investment significantly affect accounting base performance of Pakistani chemical and pharmaceutical companies. Therefore, the firm needs to consider WCM investment policies that can play an important role in enhancing firms' efficiency when making an investment decision. Furthermore, this study provides policymakers and directors guidelines for considering short-term funding arrangements and managing their shortcomings during EPU fluctuations.

\section{Practical implications}

This study will help practitioners while making an investment decision in WCM for firms because the results of this study contribute significantly to the firm's profitability. Also, this research contributes favorable to a country's prospective investors at large in the business's internal environment. Through the right investment decisions, maintain the levels WCM and can be reduced supplier cost to produce goods at competitive level. 
A. Quddus, D. Pavelková, S. Hussain, T. P. Pham. 2021. The moderating impact of economic policy uncertainty on the relationship between investment in working capital and profitability

\section{Limitations and future research}

We would like to make it obvious that no study can be escaped of obstacles as mentioned below: In this research, the researcher has collected data only from the nonfinancial sector. The financial industry can be used to carry the same study to get different results. This research focuses on the secondary data obtained from SBP officials, thus relying only on the data's validity. The reliability of the secondary data depends on the essence of the investigation. The significance of the data source will influence the estimates' results and clarify the results of the study.

\section{Funding}

The authors are thankful for providing financial support by the Internal Grant Agency of FaME TBU No. IGA/ FaME/2021/011

\section{Contribution}

Conceptualization: Abdul QUDDUS, Drahomíra PAVELKOVÁ

Formal Analysis: Abdul QUDDUS, Sarfraz HUSSAIN

Methodology: Abdul QUDDUS, Tien Phat PHAM

Validation: Abdul QUDDUS, Drahomíra PAVELKOVÁ

Funding Acquisition: Abdul QUDDUS, Drahomíra PAVELKOVÁ

Writing - original draft: Abdul QUDDUS, Sarfraz HUSSAIN, Tien Phat PHAM

Writing - review \& editing Abdul QUDDUS, Sarfraz HUSSAIN, Tien Phat PHAM

\section{Disclosure statement}

On behalf of all authors, the corresponding author states that there is no conflict of interest whatsoever.

\section{References}

Abdullah, S. \& Siddiqui, D. A. (2019). Working capital financing and corporate profitability of Pakistan manufacturing firms: Evidence from FMCG, cement \& chemical sector. Asian Journal of Economic Modelling, 7(2), 82-94. https://doi.org/10.18488/journal.8.2019.72.82.94

Afrifa, G. A. (2015). Working capital management practices and profitability of AIM listed SMEs. Journal of Enterprising Culture, 23(1), 1-23. https://doi.org/10.1142/S0218495815500016

Ahangar, N. (2021). Is the relationship between working capital management and firm profitability non-linear in Indian SMEs? Small Enterprise Research, 1-13. https://doi.org/10.1080/13215906.2021.1872685

Aktas, N., Croci, E., \& Petmezas, D. (2015). Is working capital management value-enhancing? Evidence from firm performance and investments. Journal of Corporate Finance, 30, 98-113. https://doi.org/10.1016/j.jcorpfin.2014.12.008

Almazari, A. A. (2014). The relationship between working capital management and profitability: Evidence from Saudi cement companies. Journal of Economics, Management and Trade, 4(1), 146-157. https://doi.org/10.9734/BJEMT/2014/5427

ALShubiri, F. N. (2011). The effect of working capital practices on risk management: evidence from Jordan. Global Journal of Business Research, 5(1), 39-54.

Altaf, N. \& Shah, F. (2017). Working capital management, firm performance and financial constraints: Empirical evidence from India. Asia-Pacific Journal of Business Administration, 9(3), 206-219. https://doi.org/10.1108/APJBA-06-2017-0057

Amponsah-Kwatiah, K., \& Asiamah, M. (2020). Working capital management and profitability of listed manufacturing firms in Ghana, International Journal of Productivity and Performance Management. https://doi.org/10.1108/IJPPM-02-2020-0043

Anton, S. G., \& Afloarei Nucu, A. E. (2021). The impact of working capital management on firm profitability: Empirical evidence from the Polish listed firms. Journal of Risk and Financial Management, 14(1), 9. https://doi.org/10.3390/jrfm14010009

Arellano, M., \& Bond, S. (1991). Some tests of specification for panel data: Monte Carlo evidence and an application to employment equations. The Review of Economic Studies, 58(2), 277-297. https://doi.org/10.2307/2297968

Arunkumar, O. N., \& Radharamanan, T. (2011). Analysis of effects of working capital management on corporate profitability of indian manufacturing firms. International Journal of Business Insights \& Transformation, 5(1).

Badu Ebenezer, A., \& Kwame Asiedu, M. (2013). The relationship between working capital management and profitability of listed manufacturing companies in Ghana. International Journal of Business and Social Research, 3(2), 25-34.

Baig, U., Sarwat, S., \& Godil, D. I. (2021). Relationship of working capital management and profitability of the firms - an application of unit root and co-integration test on the various corporate sectors of Pakistan stock exchange. Independent Journal of Management \& Production, 12(1), 377-394. https://doi.org/10.14807/ijmp.v12i1.1305

Baker, S. R., Bloom, N., \& Davis, S. J. (2016). Measuring economic policy uncertainty. The Quarterly Journal of Economics, 131(4), 1593-1636. https://doi.org/10.1093/qje/qjw024 
A. Quddus, D. Pavelková, S. Hussain, T. P. Pham. 2021. The moderating impact of economic policy uncertainty on the relationship between investment in working capital and profitability

Baños-Caballero, S., García-Teruel, P. J., \& Martínez-Solano, P. (2014). Working capital management, corporate performance, and financial constraints. Journal of Business Research, 67(3), 332-338. https://doi.org/10.1016/j.jbusres.2013.01.016

Blundell, R., Bond, S., \& Windmeijer, F. (2001). Estimation in dynamic panel data models: Improving on the performance of the standard GMM estimator (pp. 53-91). Emerald Group Publishing Limited. https://doi.org/10.1016/S0731-9053(00)15003-0

Bordo, M. D., Duca, J. V., \& Koch, C. (2016). Economic policy uncertainty and the credit channel: Aggregate and bank level US evidence over several decades. Journal of Financial Stability, 26, 90-106. https://doi.org/10.1016/j.jfs.2016.07.002

Chen, H., Frank, M. Z., \& Wu, O. Q. (2005). What actually happened to the inventories of American companies between 1981 and 2000? Management Science, 51(7), 1015-1031. https://doi.org/10.1287/mnsc.1050.0368

Corsten, D., \& Gruen, T. W. (2004). Stock-outs cause walkouts. Harvard Business Review, 82(5), 26-28.

Costa, B. R. D. (2014). Cash conversion cycle across industries [Doctoral dissertation]. NSBE-UNL.

Deloof, M., 2003. Does working capital management affect profitability of Belgian firms? Journal of Business Finance Accounting, 30(3-4), 573-588. https://doi.org/10.1111/1468-5957.00008

Dbouk, W., Moussawi-Haidar, L., \& Jaber, M. (2018). The detrimental effect of economic policy uncertainty on firms' working capital. https://efmaefm.org/0efmameetings/efma\%20annual\%20meetings/2018-Milan/papers/EFMA2018_0300_fullpaper.pdf

Enqvist, J., Graham, M., \& Nikkinen, J. (2014). The impact of working capital management on firm profitability in different business cycles: Evidence from Finland. Research in International Business and Finance, 32, 36-49. https://doi.org/10.1016/j.ribaf.2014.03.005

Gaur, V., \& Kesavan, S. (2015). The effects of firm size and sales growth rate on inventory turnover performance in the U.S. retail sector. In N. Agrawal \& S. Smith (Eds.), International series in operations research \& management science: Vol 223. Retail supply chain management. Springer, Boston, MA. https://doi.org/10.1007/978-1-4899-7562-1_3

Gelsomino, L. M., Mangiaracina, R., Perego, A., \& Tumino, A. (2016). Supply chain finance: a literature review. International Journal of Physical Distribution \& Logistics Management, 46(4). https://doi.org/10.1108/IJPDLM-08-2014-0173

Gilchrist, S., Sim, J. W., \& Zakrajšek, E. (2014). Uncertainty, financial frictions, and investment dynamics (No. w20038). National Bureau of Economic Research. https://doi.org/10.3386/w20038

Hambuckers, J., \& Ulm, M. (2020). Interest rate differentials and the dynamic asymmetry of exchange rates. SSRN. https://doi.org/10.2139/ssrn.3541862

Kabuye, F., Kato, J., Akugizibwe, I., \& Bugambiro, N. (2019). Internal control systems, working capital management and financial performance of supermarkets. Cogent Business \& Management, 6(1), 1573524. https://doi.org/10.1080/23311975.2019.1573524

Kang, W., Lee, K., \& Ratti, R. A. (2014). Economic policy uncertainty and firm-level investment. Journal of Macroeconomics, 39 , 42-53. https://doi.org/10.1016/j.jmacro.2013.10.006

Kesavan, S., Kushwaha, T., \& Gaur, V. (2016). Do high and low inventory turnover retailers respond differently to demand shocks?, Manufacturing \& Service Operations Management, 18(2), 198-215. https://doi.org/10.1287/msom.2015.0571

Lee, H. H., Zhou, J., \& Wang, J. (2018). Trade credit financing under competition and its impact on firm performance in supply chains. Manufacturing \& Service Operations Management, 20(1), 36-52. https://doi.org/10.1287/msom.2017.0640

Li, L., Shubik, M., \& Sobel, M. J. (2013). Control of dividends, capital subscriptions, and physical inventories. Management Science, 59(5), 1107-1124. https://doi.org/10.1287/mnsc.1120.1629

Lo, C. K., Yeung, A. C., \& Cheng, T. C. E. (2009). ISO 9000 and supply chain efficiency: empirical evidence on inventory and account receivable days. International Journal of Production Economics, 118(2), 367-374. https://doi.org/10.1016/j.ijpe.2008.11.010

Mazlan, A. R., \& Leng, C. Y. (2018). The moderating effect of working capital management on the relationship between working capital determinants and firm performance. Indian-Pacific Journal of Accounting and Finance, 2(1), 38-48.

Oseifuah, E. K., \& Gyekye, A. (2017). Working capital management and shareholders' wealth creation: Evidence from non-financial firms listed on the Johannesburg Stock Exchange. Investment Management and Financial Innovations, 14(1), 80-88. https://doi.org/10.21511/imfi.14(1).2017.08

Panda, A. K. \& Nanda, S. (2018). Working capital financing and corporate profitability of Indian manufacturing firms. Management Decision, 56(2), 441-457. https://doi.org/10.1108/MD-07-2017-0698

Pastor, L., \& Veronesi, P. (2012). Uncertainty about government policy and stock prices. The journal of Finance, 67(4), $1219-1264$. https://doi.org/10.1111/j.1540-6261.2012.01746.x

Pfohl, H. C., \& Gomm, M. (2009). Supply chain finance: optimizing financial flows in supply chains. Logistics Research, 1 (3-4), 149-161. https://doi.org/10.1007/s12159-009-0020-y

Prasad, P., Narayanasamy, S., Paul, S., Chattopadhyay, S., \& Saravanan, P. (2019). Review of literature on working capital management and future research agenda. Journal of Economic Surveys, 33(3), 827-861. https://doi.org/10.1111/joes.12299

Ren, T., Liu, N., Yang, H., Xiao, Y., \& Hu, Y. (2019). Working capital management and firm performance in China. Asian Review of Accounting, 27(4), 546-562. https://doi.org/10.1108/ARA-04-2018-0099

Sahari, S., Tinggi, M., \& Kadri, N. (2012). Inventory management in Malaysian construction firms: impact on performance. SIU Journal of Management, 2(1), 59-72.

Sattar, A. R. (2019). Does working capital management play mediating role? Determinants of capital structure. European Online Journal of Natural and Social Sciences, 8(2), 309-315.

Seifert, R. W., Tancrez, J.-S., \& Biçer, I., (2016). Dynamic product portfolio management with life cycle considerations. International Journal of Production Economics, 171, 71-83. https://doi.org/10.1016/j.ijpe.2015.10.017

Sharma, A., \& Kumar, S. (2011). Effect of working capital management on firm profitability empirical evidence from India. Global Business Review, 12(1), 159-173. https://doi.org/10.1177/097215091001200110 
A. Quddus, D. Pavelková, S. Hussain, T. P. Pham. 2021. The moderating impact of economic policy uncertainty on the relationship between investment in working capital and profitability

Siraj, M. L., Aslinda, A., Awaluddin, M., Kasmita, M., \& Taddampali, A. C. T. (2021). The company's working capital during the Covid-19 pandemic to increase the profitability limited company Telkomsel in Makassar City. Pinisi Business Administration Review, 2(2), 135-140.

Theodore Farris, M., \& Hutchison, P. D. (2002). Cash-to-cash: the new supply chain management metric. International Journal of Physical Distribution \& Logistics Management, 32(4), 288-298. https://doi.org/10.1108/09600030210430651

Ukaegbu, B. (2014). The significance of working capital management in determining firm profitability: Evidence from developing economies in Africa. Research in International Business and Finance, 31, 1-16. https://doi.org/10.1016/j.ribaf.2013.11.005

Wang, Y., Chen, C. R., \& Huang, Y. S. (2014). Economic policy uncertainty and corporate investment: evidence from China. Pacific-Basin Finance Journal, 26, 227-243. https://doi.org/10.1016/j.pacfin.2013.12.008

Wuttke, D. A., Blome, C., \& Henke, M. (2013). Focusing the financial flow of supply chains: An empirical investigation of financial supply chain management. International Journal of Production Economics, 145(2), 773-789.

https://doi.org/10.1016/j.ijpe.2013.05.031 